\title{
Extracellular Acid and Alkaline Proteases from Candida olea
}

\author{
By G. NELSON† AND T. W. YOUNG* \\ Department of Biochemistry, University of Birmingham, PO Box 363, Birmingham B15 2TT, UK
}

(Received 16 December 1986; revised 13 February 1987)

Candida olea 148 secreted a single acid protease when cultured at acidic $\mathrm{pH}$. In unbuffered medium, the culture pH eventually became alkaline and a single alkaline protease was produced. This was the only proteolytic enzyme produced when the organism was grown in buffered medium at alkaline $\mathrm{pH}$. Both proteolytic enzymes were purified to homogeneity (as assessed by SDS-PAGE). The $M_{\mathrm{r}}$ of the acid protease was 30900 , the isoelectric point 4.5 ; optimum activity against haemoglobin was at $42^{\circ} \mathrm{C}$ and $\mathrm{pH} 3 \cdot 3$. This enzyme was inactivated at temperatures above $46^{\circ} \mathrm{C}$ and was inhibited by pepstatin and diazoacetyl-norleucine methyl ester but was insensitive to inhibition by either 1,2-epoxy-3-( $p$-nitrophenoxy)-propane or compounds known to inhibit serine, thiol or metallo proteases. The acid protease contained $11 \%$ carbohydrate. The alkaline protease had an $M_{\mathrm{r}}$ of 23400 and an isoelectric point of 5.4 . The activity of this enzyme using azocoll as substrate was optimal at $40^{\circ} \mathrm{C}$ in the range pH $8 \cdot 0-9 \cdot 0$. This enzyme was inactivated at temperatures above $42^{\circ} \mathrm{C}$ and was inhibited by phenylmethylsulphonyl fluoride and irreversibly inactivated by EDTA. The enzyme was also partially inhibited by DTT but was insensitive to either pepstatin or $p$-chloromercuribenzoic acid.

\section{INTRODUCTION}

Several yeasts have been shown to secrete proteolytic enzymes (Ekland et al., 1965; Ahearn et al., 1968; Foda \& El-Din, 1979). Strains most actively secreting such enzymes were found in the genera Candida, Endomycopsis, Rhodotorula and Kluyveromyces. The acid protease secreted by Candida albicans has been particularly well studied because of its possible role in the pathogenicity of the organism. This enzyme is a single polypeptide with an $M_{\mathrm{r}}$ of 45000 (Remold et al., 1968; Ruchel, 1981). Antibodies to this protease have been used as diagnostic agents for the detection of candidosis in man (MacDonald \& Odds, 1980).

Strains of Saccharomycopsis lipolytica secrete a number of different extracellular proteases active at acidic, neutral and alkaline $\mathrm{pH}$. When cultured at acidic $\mathrm{pH}$, strain CX161-1B produced three carboxyl proteases (Yamada \& Ogrydziak, 1983). Production of each protease varied during growth, suggesting separate regulatory pathways for their synthesis. When cultured at neutral $\mathrm{pH}$, the same strain produced virtually no carboxyl proteases but high levels of an alkaline serine protease were found (Ogrydziak \& Scharf, 1982). Another strain grown at neutral or alkaline $\mathrm{pH}$ secreted an enzyme active only at neutral $\mathrm{pH}$ (Abdelal et al., 1977).

Other yeast extracellular proteases examined in detail include those secreted by Rhodotorula glutinis and Candida lipolytica. The former strain produced an acid protease inhibited by Streptomyces maniuraensis pepsin inhibitor and by diazoacetyl-norleucine methyl ester (DAN) (Kamada et al., 1972). C. lipolytica secreted a single alkaline serine protease (Tobe et al., 1976).

An uncharacterized extracellular protease prepared from the yeast Candida olea 148 was shown to have potential use in the brewing industry as a replacement for the plant thiol protease

† Present address: The Shirley Institute, Didsbury, Manchester M20 8RX, UK

Abbreviations: DAN, diazoacetyl-norleucine methyl ester; EPNP, 1,2-epoxy-3-( $p$-nitrophenoxy)-propane; PCMB, p-chloromercuribenzoic acid; PMSF, phenylmethylsulphonyl fluoride. 
papain, which is used to prevent the formation of chill-haze in beer (Nelson \& Young, 1986). This paper describes the production, purification and characterization of the extracellular proteolytic enzymes present in the beer chill-proofing preparation.

\section{METHODS}

Maintenance and culture of yeast. Candida olea 148 (from the yeast collection of the Department of Food Science and Technology, University of California, Davis, USA) was maintained by regular subculture on medium comprising (w/v): yeast extract, $0.3 \%$; malt extract, $0.3 \%$; bacteriological peptone, $0.5 \%$; glucose, $2.0 \%$; and agar, $2.0 \%$. Starter cultures were grown on medium without agar.

Medium for protease production. Starter cultures $(10 \mathrm{ml})$ grown at $29^{\circ} \mathrm{C}$ were inoculated into 1 litre of medium $1 \%(w / v)$ glucose, $0.2 \%$ BSA and $0.17 \%$ Difco yeast-nitrogen-base without amino acids and ammonium sulphate in a 2 litre Erlenmeyer flask. BSA and yeast-nitrogen-base were sterilized by filtration through $0.22 \mu \mathrm{m}$ membranes and aseptically added to an aqueous glucose solution previously sterilized by autoclaving at $15 \mathrm{lbf} \mathrm{in}^{-2}$ $(103.5 \mathrm{kPa}$ ) for $15 \mathrm{~min}$. For experiments requiring controlled values of $\mathrm{pH}$ in the range 2-8, citrate-phosphate buffers were used (prepared from $0.1 \mathrm{M}$-citric acid and $0.2 \mathrm{M}$ disodium hydrogen phosphate, by mixing appropriate volumes to give $100 \mathrm{ml}$ buffer in which the medium constituents were dissolved). For cultures at $\mathrm{pH} 9, \mathrm{Tris} / \mathrm{HCl}$ buffer at a final concentration in the medium of $0.1 \mathrm{M}$ was used. The $\mathrm{pH}$ values of these cultures remained constant throughout fermentation. Cultures were incubated at $29^{\circ} \mathrm{C}$ on a rotary shaker at 120 r.p.m. and were harvested by centrifugation $(5000 \mathrm{~g}, 10 \mathrm{~min})$ at $4^{\circ} \mathrm{C}$. Sodium azide was added to the supernatant to a final concentration of $0.02 \%$ before proceeding with enzyme purification.

Assay of acid protease. Proteolytic activity was estimated by measuring the hydrolysis of a standard haemoglobin substrate by a method based on that of Remold et al. (1968). Enzyme solution $(0.5 \mathrm{ml})$ was added to $2.0 \mathrm{ml}$ of acid denatured haemoglobin $(1.0 \%, \mathrm{w} / \mathrm{v}$, in $0.05 \mathrm{M}$-sodium citrate buffer $\mathrm{pH} 3.2)$ and incubated at $37^{\circ} \mathrm{C}$ for $30 \mathrm{~min}$. The reaction was stopped by the addition of $5 \mathrm{ml} 5.0 \%(\mathrm{w} / \mathrm{v})$ trichloroacetic acid and the precipitate was removed by centrifugation. A sample of the supernatant $(2.0 \mathrm{ml})$ was neutralized by the addition of $1.0 \mathrm{ml} 0.5 \mathrm{M}-\mathrm{NaOH}$ and $0.8 \mathrm{ml}$ of this solution was assayed for the presence of soluble peptides by the Lowry method using tyrosine as a standard. One unit $(\mathrm{U})$ of enzyme activity was defined as that amount which released $1 \mu$ mol tyrosine equivalents (ml enzyme solution) ${ }^{-1} \mathrm{~min}^{-1}$. During column chromatography, proteolytic activity was located by measuring the absorbance of the un-neutralized supernatant at $280 \mathrm{~nm}$.

Assay of alkaline protease. Azocoll (Sigma) was used as substrate and the method was based on that of Moore (1969). Enzyme solution $(0.5 \mathrm{ml})$ was mixed with $2.5 \mathrm{ml} 0.6 \%$ azocoll in $0.2 \mathrm{M}$ Tris buffer $\mathrm{pH} 7.5$. The mixture was incubated with shaking at $37^{\circ} \mathrm{C}$ for $30 \mathrm{~min}$ and the reaction stopped by removing the insoluble azocoll by centrifugation. The absorbance of the supernatant was measured at $520 \mathrm{~nm}$ against a reagent blank prepared by removing the azocoll at time 0 . The enzyme activity was expressed as change in $A_{520}(\mathrm{ml} \text { of enzyme solution) })^{-1}$ $\min ^{-1}$.

Assay of protein. The Lowry method was used with BSA as the standard. Elution of proteinaceous material during column chromatography was monitored continuously at $280 \mathrm{~nm}$ using an Altex $150 \mathrm{UV}$ monitor equipped with a $0.5 \mathrm{~mm}$ pathlength flow cell.

Assay of carbohydrate. Carbohydrate concentration was measured by the phenol/sulphuric acid method (Ashwell, 1966) with glucose as the standard.

Purification of proteolytic enzymes. Purification of the acid and alkaline proteases was based on the methods of Yamada \& Ogrydziak (1983) and Ogrydziak \& Scharf (1982) respectively. All enzyme purification steps were conducted at $4{ }^{\circ} \mathrm{C}$. Cell free supernatants were concentrated through a Diaflo PM10 membrane (Amicon).

Acid protease. (a) Gel permeation chromatography. A $5 \mathrm{ml}$ portion of concentrate was chromatographed on a $95 \times 2.6 \mathrm{~cm}$ column of Sephadex G-75 equilibrated in $0.01 \mathrm{M}$-sodium citrate buffer $\mathrm{pH} 3.2$. Fractions containing proteolytic activity were pooled.

(b) Ion-exchange chromatography. The pooled fractions containing proteolytic activity from gel-permeation chromatography were dialysed for $16 \mathrm{~h}$ against $0.01 \mathrm{M}$-sodium citrate buffer $\mathrm{pH} 6.0$ and applied to $25 \times 2.6 \mathrm{~cm}$ column of Whatman DE 52 ion-exchange cellulose equilibrated with the same buffer. The column was eluted with a $400 \mathrm{ml}$ linear gradient from 0 to $1.0 \mathrm{M}-\mathrm{NaCl}$ in $0.01 \mathrm{M}$-sodium citrate buffer $\mathrm{pH} \mathrm{6.0.} \mathrm{Fractions} \mathrm{containing}$ proteolytic activity were pooled, dialysed for $16 \mathrm{~h}$ against distilled water and freeze-dried.

Alkaline protease (a) Gel-permeation chromatography. The same procedure was used as for the acid protease except that the column was equilibrated and eluted with $0.03 \mathrm{M}$-sodium phosphate buffer $\mathrm{pH} 6.8$.

(b) Ion-exchange chromatography. The same procedure was used as for the acid protease except that the column was equilibrated with $0.01 \mathrm{M}$-Tris/ $\mathrm{HCl}$ buffer $\mathrm{pH} 8.4$ and eluted with a $400 \mathrm{ml}$ linear gradient of $0-1.0 \mathrm{M}-\mathrm{NaCl}$ in the same buffer.

Polyacrylamide gel electrophoresis. Freeze-dried protease preparations were dissolved in sample buffer $[0.0625 \mathrm{M}$-Tris/ $\mathrm{HCl}, \mathrm{pH} 6.8,20 \%(\mathrm{v} / \mathrm{v})$ glycerol, $2 \%(\mathrm{v} / \mathrm{v}) 2$-mercaptoethanol, $6 \%(\mathrm{w} / \mathrm{v}) \mathrm{SDS}]$ heated to $100{ }^{\circ} \mathrm{C}$ for $4 \mathrm{~min}$, cooled to ambient temperature and clarified by centrifugation. Samples were subjected to electrophoresis 
on a linear $(5-20 \%, \mathrm{w} / \mathrm{v})$ acrylamide gradient in $0.375 \mathrm{M}$-Tris $/ \mathrm{HCl}, \mathrm{pH} 8.8$, according to the method described by Hames (1981). A $2 \cdot 5 \%$ acrylamide stacking gel was used in $0 \cdot 125 \mathrm{M} \mathrm{Tris} / \mathrm{HCl}, \mathrm{pH} 6.8$. Gels were electrophoresed at $20{ }^{\circ} \mathrm{C}$ at $100 \mathrm{~V}$ during stacking and then at $180 \mathrm{~V}$. Gel slabs were fixed in methanol/glacial acetic acid/water (43:7:50, by vol.) and stained with $0.2 \%$ Page Blue $83(\mathrm{BDH})$. Destaining was achieved using absolute ethanol/glacial acetic acid/water (43:7:50 by vol.).

Isoelectric focussing. LKB Ampholine PAG plates, pH 3.0-9.5, were used. Gels were focussed on an LKB multiphor for $1.5 \mathrm{~h}$. An LKB 2917 power source was used and focussing was conducted at $30 \mathrm{~W}, 1500 \mathrm{~V}$ and $50 \mathrm{~mA}$. Samples were focussed alongside standards with known isoelectric points (pH 4.7-1.0, BDH). Gels were stained with Page Blue 83 or layered onto agar medium containing either precipitated casein $-0.375 \%$ casein, $3 \%$ (w/v) agar in $0.05 \mathrm{M}$-sodium citrate buffer $\mathrm{pH} 4.2$ - or gelatine $-1 \%(\mathrm{w} / \mathrm{v})$ gelatine, $3 \%$ agar in $0.3 \mathrm{M}-\mathrm{Tris} / \mathrm{HCl}$, $\mathrm{pH} 7 \cdot 5$ - to identify proteolytic activity.

pH and temperature characteristics. The $\mathrm{pH}$ optimum of each protease was determined using haemoglobin (acid protease) or azocoll (alkaline protease) as substrates. Haemoglobin $(1 \%$ w/v) was prepared in citrate-phosphate buffers of $\mathrm{pH} 2 \cdot 2-8 \cdot 0$. For $\mathrm{pH}$ values above $8 \cdot 0$, Tris/ $\mathrm{HCl}$ buffers were used. For values less than $\mathrm{pH} 2 \cdot 0$, the solution $\mathrm{pH}$ was adjusted with $3.0 \mathrm{M}-\mathrm{HCl}$. Azocoll substrate was added to the same range of solutions for the assay of alkaline protease activity. Enzyme activity was expressed as a percentage of the maximum activity attained. Enzyme preparations were dialysed for $16 \mathrm{~h}$ at $4{ }^{\circ} \mathrm{C}$ against sodium phosphate buffer $(0 \cdot 1 \mathrm{M}, \mathrm{pH} 6 \cdot 8)$ before assay. For determining the optimum temperature under the conditions of assay, assays were done at a range of temperatures from 0 to $60^{\circ} \mathrm{C}$.

Inhibition of protease activity. Stock inhibitor solutions were prepared, diluted with assay buffer and added to enzyme solution $(1: 1)$. Each inhibitor was added so that the final concentration would be either $10 \mathrm{mM}$ or $1 \mathrm{mM}$, except for pepstatin $\mathrm{A}$ which was added at $100 \mu \mathrm{M}, 10 \mu \mathrm{M}$, and $1 \mu \mathrm{M}$ final concentration and p-chloromercuribenzoate (PCMB) where only $1 \mathrm{mM}$ final concentration was used.

Stock solutions were prepared by dissolving phenylmethylsulphonyl fluoride (PMSF) in propan-2-ol, PCMB in dilute alkali (10 mM-NaOH), EDTA in water, pepstatin $A$ in $50 \%(v / v)$ aqueous methanol, 1,2-epoxy-3-( $p$ nitrophenoxy)-propane (EPNP) in methanol and dilute alkali (10 mM-NaOH), DAN in methanol and DTT in water. $4 \mathrm{~mm}$ - and $1 \mathrm{~mm}$-cupric acetate was included in the $10 \mathrm{~mm}$ - and $1 \mathrm{~mm}$-EPNP and DAN assays mixes respectively.

The enzyme/inhibitor mixes were incubated at $37^{\circ} \mathrm{C}$ for $30 \mathrm{~min}$ and the enzyme activity was measured relative to an uninhibited control. Controls without inhibitor but containing solvents used to dissolve inhibitors were also included: enzyme activity was not affected. Activity was measured using either haemoglobin or azocoll as substrate as above. The EPNP-enzyme mixture required preincubation at $4{ }^{\circ} \mathrm{C}$ for $20 \mathrm{~h}$ before the $30 \mathrm{~min}$ incubation at $37^{\circ} \mathrm{C}$.

The action of various metal ions on protease activity was also recorded. Divalent cations ( $1 \mathrm{~mm}$ final concentration) were mixed with the enzyme, which was assayed as above.

In all studies of inhibition and effect of metal ions on enzyme activity, replicate experiments agreed within $\pm 3 \%$ of enzyme activity.

\section{RESULTS AND DISCUSSION}

\section{Protease production}

Growth and protease production by $C$. olea 148 were monitored for $14 \mathrm{~d}$ in culture in unbuffered medium containing BSA as the sole nitrogen source and glucose as carbon source (Fig. 1). The initial pH of the medium was close to $\mathrm{pH} 4.6$ and after inoculation of $C$. olea, acid protease activity was detected throughout the growth phase as found previously in some S. lipolytica strains (Tobe et al., 1976; Abdelal et al., 1977; Ogrydziak et al., 1977). Activity increased throughout the growth phase and early stationary phase to a maximum of $115 \mathrm{U}$ (tyrosine) at $5 \mathrm{~d}$ incubation. At this point there was a dramatic reduction in acid protease activity such that only $7.8 \mathrm{U}$ (tyrosine) of activity remained at day 7 . No alkaline protease activity was detected during the growth and early stationary phases. However, on day 6 some alkaline protease activity was detected and this increased to a maximum of $3.5 \mathrm{U}\left(A_{520}\right)$ after $9 \mathrm{~d}$ incubation (Fig. 1). Cell lysis was not detected but the sharp reduction in acid protease activity and the onset of alkaline protease activity was associated with a dramatic increase in $\mathrm{pH}$ from around $\mathrm{pH} 3.0$ after $3 \mathrm{~d}$ incubation to $\mathrm{pH} 7.0$ after $5 \mathrm{~d}$ (Fig. 1). The secretion of alkaline protease was directly related to the increasing $\mathrm{pH}$ of the medium. This was confirmed when $C$. olea 148 was grown in the same liquid medium, but where the $\mathrm{pH}$ was regulated between $\mathrm{pH} 2 \cdot 0$ and $\mathrm{pH} 9.0$ (Fig. 2). In cultures above $\mathrm{pH} 8.0$ no acid protease activity was detected and at $\mathrm{pH}$ 

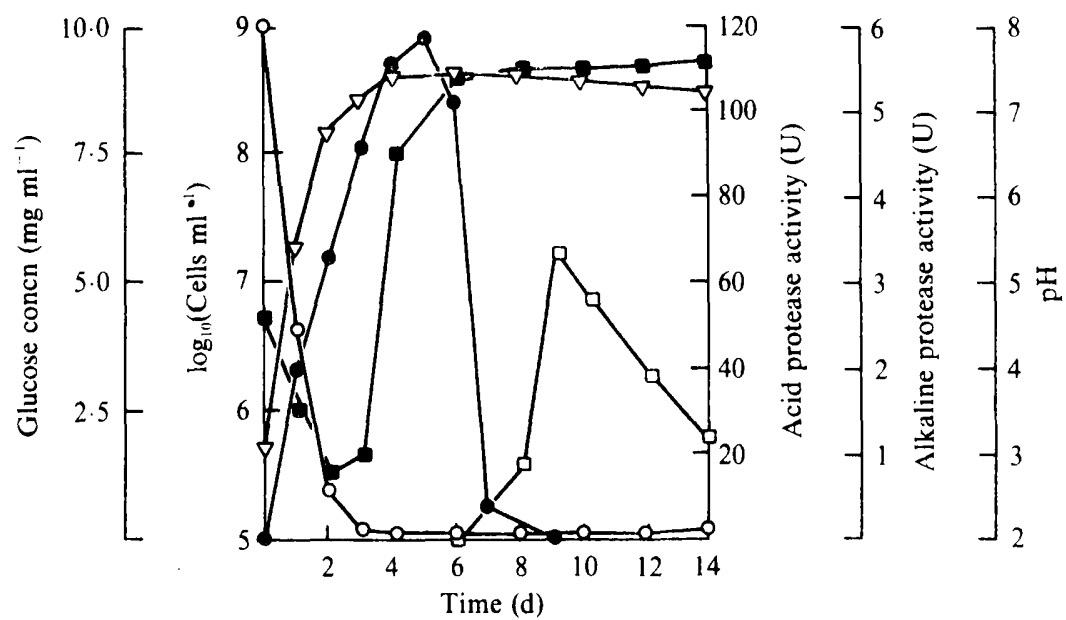

Fig. 1. Production of extracellular protease by $C$. olea 148 grown in unbuffered 1 litre shaken culture at $29^{\circ} \mathrm{C}$. $\mathrm{O}$, Glucose, $\mathrm{mg} \mathrm{ml}^{-1} ; \nabla, \log _{10}\left(\right.$ cell number $\left.\mathrm{ml}^{-1}\right) ; 0$, acid protease activity ( $\mu \mathrm{mol}$ tyrosine equivalents released $\mathrm{ml}^{-1} \mathrm{~min}^{-1}$ from haemoglobin at $\mathrm{pH} 3 \cdot 2$ ); $\square$, alkaline protease activity (change in $A_{520} \mathrm{ml}^{-1} \mathrm{~min}^{-1}$ on hydrolysis of azocoll at $\left.\mathrm{pH} 7 \cdot 5\right) ; \mathrm{aH}$ of culture.
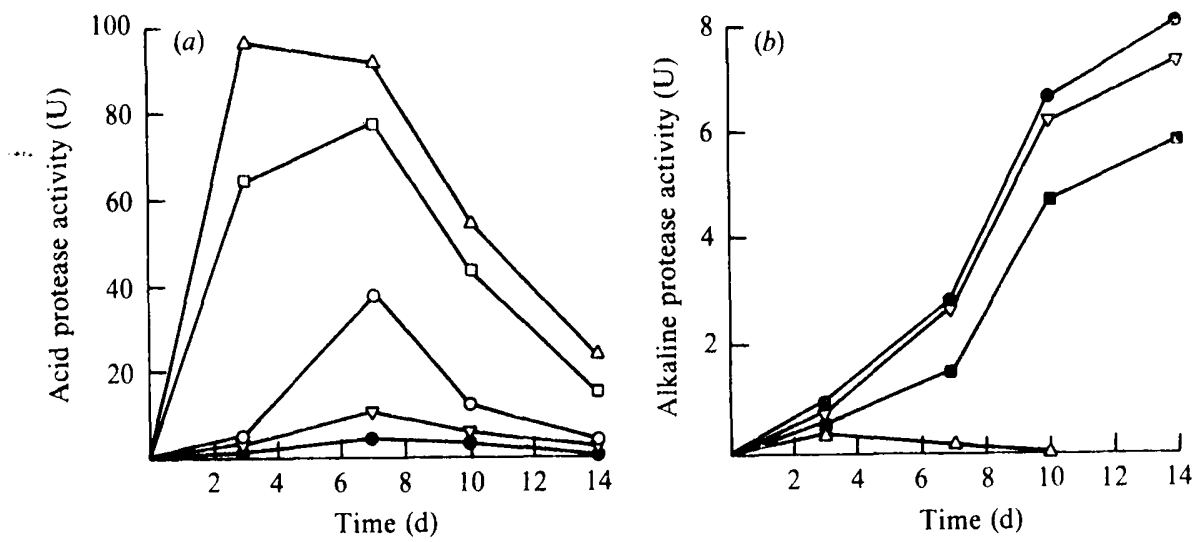

Fig. 2. Production of acid and alkaline extracellular proteases by $C$. olea 148 grown in buffered 1 litre shaken culture at $29^{\circ} \mathrm{C}$. (a) Acid protease activity ( $\mu \mathrm{mol}$ tyrosine equivalents released $\mathrm{ml}^{-1} \mathrm{~min}^{-1}$ from haemoglobin at $\mathrm{pH} \mathrm{3.2).} \mathrm{(b)} \mathrm{Alkaline} \mathrm{protease} \mathrm{activity} \mathrm{(change} \mathrm{in} A_{520} \mathrm{ml}^{-1} \mathrm{~min}^{-1}$ on hydrolysis of azocoll at $\mathrm{pH} 7.5)$. Culture buffered with citrate-phosphate $\mathrm{pH} 2(O), \mathrm{pH} 4(\square), \mathrm{pH} 6(\triangle), \mathrm{pH} 7(\nabla)$, $\mathrm{pH} 8(\mathrm{O})$. Culture buffered with $0.1 \mathrm{M}-\mathrm{Tris} / \mathrm{HCl} \mathrm{pH} 9(\mathbf{U})$. No acid protease activity was detected at $\mathrm{pH}$ values $>8$ and no alkaline protease activity was detected at $\mathrm{pH}<6$.

less than 6.0 no alkaline protease activity was detected. When $\mathrm{pH}$ was controlled, alkaline protease secretion in alkaline culture began as with acid culture, during the growth phase and increasing into early stationary phase. However, the alkaline protease secretion continued to increase well into stationary phase and above $\mathrm{pH} 7.0$ reached a maximum of about $9 \mathrm{U}\left(A_{520}\right)$ after $14 \mathrm{~d}$. In the initial culture, with no $\mathrm{pH}$ control, the concentration of glucose was monitored and was found to be only $50 \%$ depleted after $14 \mathrm{~h}$ at which point the acid protease activity was $40 \mathrm{U}$ (tyrosine). Therefore carbon depletion was not necessary for initiation of acid protease production (see Fig. 1).

\section{Purification of the proteases}

The protease activity produced by $C$. olea 148 was isolated from the culture supernatant obtained from $7 \mathrm{~d}$ growth in unbuffered medium and concentrated by ultrafiltration (Table 1 ). 


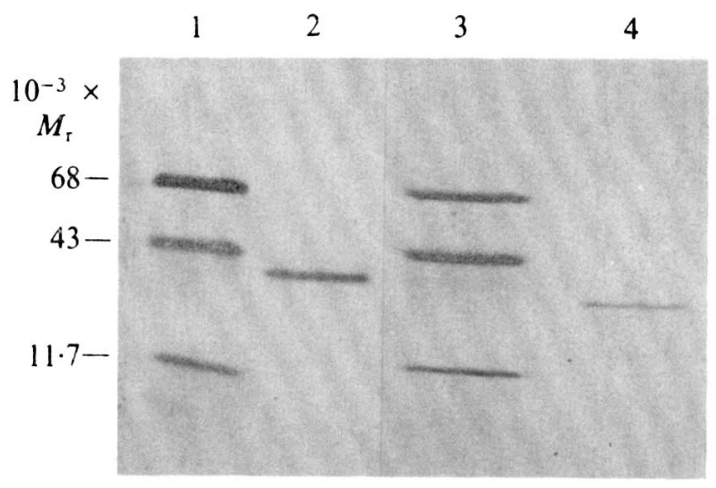

Fig. 3. SDS-PAGE of purified acid and alkaline proteases from $C$. olea 148. Lanes 1 and 3, BSA $(68000)$, ovalbumin $(43000)$, cytochrome $c(11700)(5 \mu \mathrm{g}$ each); lane 2 , acid protease preparation $(10 \mu \mathrm{g})$; lane 4 , alkaline protease preparation $(20 \mu \mathrm{g})$.

Table 1. Purification of acid and alkaline extracellular proteases secreted by C. olea 148

\begin{tabular}{|c|c|c|c|c|c|}
\hline & $\begin{array}{l}\text { Volume } \\
\text { (ml) }\end{array}$ & $\begin{array}{l}\text { Total } \\
\text { activity† } \\
\text { (U) }\end{array}$ & $\begin{array}{l}\text { Total } \\
\text { protein* } \\
(\mathrm{mg})\end{array}$ & $\begin{array}{c}\text { Specific } \\
\text { activity } \\
\left(\mathrm{U} \mathrm{mg}^{-1}\right)\end{array}$ & $\begin{array}{c}\text { Recovery } \\
(\%)\end{array}$ \\
\hline \multicolumn{6}{|l|}{ Acid protease } \\
\hline Supernatant & 1500 & 14850 & 600 & 25 & 100 \\
\hline Ultrafiltrate & 5 & 14198 & 278 & 51 & $95 \cdot 6$ \\
\hline Sephadex G-75 & 114 & 13178 & $15 \cdot 4$ & 856 & $92 \cdot 8$ \\
\hline DEAE-cellulose & 63 & 8962 & $2 \cdot 4$ & 3703 & $60 \cdot 4$ \\
\hline \multicolumn{6}{|l|}{ Alkaline protease } \\
\hline Supernatant & 1000 & 48 & 573 & 0.084 & 100 \\
\hline Ultrafiltrate & 5 & $45 \cdot 9$ & 236 & $0 \cdot 195$ & $95 \cdot 6$ \\
\hline Sephadex G-75 & 66 & $38 \cdot 4$ & $14 \cdot 5$ & $2 \cdot 64$ & $80 \cdot 0$ \\
\hline DEAE-cellulose & 38 & $25 \cdot 1$ & $4 \cdot 4$ & $5 \cdot 64$ & $52 \cdot 3$ \\
\hline
\end{tabular}

* Protein concentration calculated using the Lowry method.

+ Acid protease activity, haemoglobin hydrolysis at $\mathrm{pH} 3 \cdot 2 ; 1 \mathrm{U}=1 \mu \mathrm{mol}$ tyrosine released $\mathrm{ml}^{-1} \mathrm{~min}^{-1}$. Alkaline protease activity, azocoll hydrolysis at $\mathrm{pH} 7.5 ; 1 \mathrm{U}=$ change in $A_{520} \mathrm{ml}^{-1} \mathrm{~min}^{-1}$.

This material contains less than the maximum concentrations of acid and alkaline protease activity that could be achieved in culture at controlled pH (Fig. 2). However, it was the material containing both enzymes which was used to chill-proof beer (Nelson \& Young, 1986) and which was selected for purification studies. Acid protease alone may be produced by culture at $\mathrm{pH} 4.6$ and alkaline protease by culture at $\mathrm{pH} 8$ (Fig. 2) and may be purified by the same procedures described here.

Gel filtration chromatography on a Sephadex G-75 column gave a single peak of acid protease activity eluting at $220-234 \mathrm{ml}$. The protease activity was determined using haemoglobin hydrolysis at $\mathrm{pH} 3 \cdot 2$. The fractions containing proteolytic activity were pooled and applied to a DEAE-cellulose column and a single peak of acid protease activity was eluted at $170-240 \mathrm{ml}$ after applying a $400 \mathrm{ml}$ linear gradient of $0-1.0 \mathrm{M}-\mathrm{NaCl}$ in $0.01 \mathrm{M}$-sodium citrate $\mathrm{pH} 6$. A 148fold purification was achieved and $60 \%$ of the total activity was recovered (Table 1 ). The active fractions were pooled, lyophilized and resolved on an SDS-polyacrylamide gel and found to be homogeneous (Fig. 3), the principal component had an $M_{\mathrm{r}}$ of 29500 . This purified preparation was tested for alkaline protease activity using urea denatured haemoglobin (Laskowski, 1955) and azocoll. No activity was found.

Cell free supernatants from $7 \mathrm{~d}$ cultures (uncontrolled $\mathrm{pH}$ ), however, did contain alkaline protease activity when assayed using azocoll as substrate. Such supernatants were concentrated and chromatographed on Sephadex-G75, alkaline protease activity eluted as a single component at $260-326 \mathrm{ml}$ and the active fractions were pooled and subjected to ion exchange 

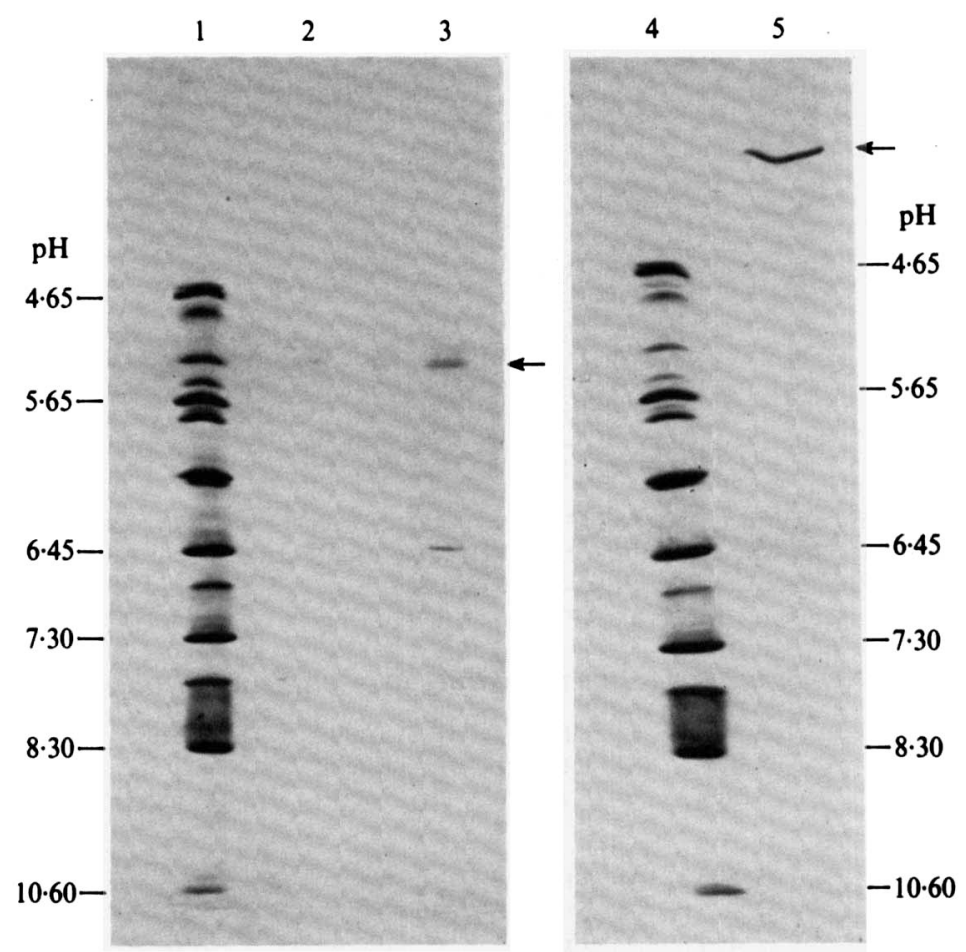

Fig. 4. Isoelectric focussing ( $\mathrm{pH} \mathrm{3.5-9.0)} \mathrm{of} \mathrm{extracellular} \mathrm{acid} \mathrm{and} \mathrm{alkaline} \mathrm{protease.} \mathrm{Lanes} 1$ and 4, isoelectric point markers pI 4.7-10.6; lanes 2 and 3, alkaline protease ( 5 and $10 \mu \mathrm{g}$ respectively); lane 5 , acid protease $(10 \mu \mathrm{g})$. Arrows identify components exhibiting proteolytic activity on medium containing gelatin. The $\mathrm{pI}$ values of the markers are shown.

chromatography. A single peak of activity was detected $200-240 \mathrm{ml}$ after applying a $400 \mathrm{ml}$ linear gradient of $0-0.15 \mathrm{M}-\mathrm{NaCl}$ in $0.01 \mathrm{M}$-Tris/ $\mathrm{HCl} \mathrm{pH} 8.4$. A 67 -fold purification was achieved and $52 \%$ of the total activity was recovered (Table 1). Analysis of this material by SDSPAGE revealed a single component (Fig. 3) of $M_{\mathrm{r}} 24000$.

\section{Estimation of $M_{r}$ by gel permeation chromatography}

Native acid and alkaline proteases were chromatographed on Sephadex-G75 and their elution volumes compared with those of proteins of known $M_{\mathrm{r}}$ (BSA, 68000; ovalbumin, 43000; myoglobin, 17200; and cytochrome $c, 11700$ ). Four independent analyses were made for each enzyme and the estimated $M_{\mathrm{r}}$ values (mean $\pm \mathrm{SD}$ ) for the acid and alkaline proteases were $30900 \pm 380$ and $23400 \pm 680$. These values agree well with those estimated by SDS-PAGE (29500 and 24000 respectively) and indicate that both enzymes are monomers in the native state.

\section{Carbohydrate content}

Samples of both the acid and alkaline proteases when resolved on SDS-polyacrylamide gels were stained pink using perchloric acid and Schiff's reagent according to the method of Zaccharius et al. (1969) and are therefore judged to be glycoproteins. The carbohydrate content of pure samples of the alkaline and the acid protease, calculated using the phenol/sulphuric acid method described by Ashwell (1966), was $11 \%$ and $17 \%$ carbohydrate respectively.

\section{Isoelectric point}

The isoelectric points of the proteases were determined using crude enzyme samples and the proteolytic activity of the resolved protease bands was confirmed by laying the gels on casein or gelatin plates. The isoelectric point of the acid protease was $<\mathrm{pH} 4.65$ and that of the alkaline protease was $\mathrm{pH} 5.4$ (Fig. 4). 
Table 2. Effect of inhibitors on the activity of the acid and alkaline proteases secreted by C. olea 148

\begin{tabular}{|c|c|c|c|}
\hline \multirow[b]{2}{*}{ Inhibitor } & \multirow{2}{*}{$\underset{(\mathrm{mM})}{\text { Concn }}$} & \multicolumn{2}{|c|}{ Activity remaining (\%) } \\
\hline & & Acid protease & Alkaline protease \\
\hline Control† & - & 100 & 100 \\
\hline PMSF & $\begin{array}{r}1 \\
10\end{array}$ & $\begin{array}{l}96 \\
96\end{array}$ & $\begin{array}{l}0 \\
0\end{array}$ \\
\hline PCMB & 1 & 106 & 97 \\
\hline EDTA & $\begin{array}{r}1 \\
10\end{array}$ & $\begin{array}{l}117 \\
107\end{array}$ & $\begin{array}{l}3 \\
0\end{array}$ \\
\hline EDTA $\ddagger$ & $\begin{array}{r}1 \\
10\end{array}$ & - & $\begin{array}{l}96 \\
74\end{array}$ \\
\hline EDTA & $\begin{array}{r}1\left(+1 \mathrm{mM}-\mathrm{Ca}^{2+}\right) \\
10\left(+1 \mathrm{mM}-\mathrm{Ca}^{2+}\right)\end{array}$ & - & $\begin{array}{r}101 \\
75\end{array}$ \\
\hline DAN & $\begin{array}{r}1\left(+1 \mathrm{~mm}-\mathrm{Cu}^{2+}\right) \\
10\left(+1 \mathrm{~mm}-\mathrm{Cu}^{2+}\right)\end{array}$ & $\begin{array}{l}91 \\
58\end{array}$ & $\overline{-}$ \\
\hline EPNP & $\begin{array}{r}1\left(+1 \mathrm{~mm}-\mathrm{Cu}^{2+}\right) \\
10\left(+1 \mathrm{~mm}-\mathrm{Cu}^{2+}\right)\end{array}$ & $\begin{array}{l}104 \\
107\end{array}$ & - \\
\hline Pepstatin & $\begin{array}{l}0.001 \\
0.01 \\
0.1\end{array}$ & $\begin{array}{l}70 \\
56 \\
22\end{array}$ & $\frac{-}{103}$ \\
\hline DTT & $\begin{array}{r}1 \\
10\end{array}$ & $\begin{array}{l}106 \\
102\end{array}$ & $\begin{array}{l}83 \\
34\end{array}$ \\
\hline
\end{tabular}

- Concentration of inhibitor in enzyme/inhibitor preincubation mixture.

$\dagger$ The acid protease activity of the control was $25 \mu \mathrm{mol}$ tyrosine released $\mathrm{ml}^{-1} \mathrm{~min}^{-1}$ measured by haemoglobin hydrolysis at $\mathrm{pH} 3 \cdot 2$. The alkaline protease activity of the control (change in $A_{520} \mathrm{ml}^{-1} \mathrm{~min}^{-1}$ ) was 1.12 using azocoll at $\mathrm{pH} 7.5$.

$\ddagger$ Measured after dialysis against buffer not containing EDTA.

\section{pH and temperature characteristics}

The $\mathrm{pH}$ stability was determined using haemoglobin hydrolysis at $\mathrm{pH} 3 \cdot 2$, for acid protease, and azocoll hydrolysis at $\mathrm{pH} 7.5$, for alkaline protease, after preincubation for between 0 and $60 \mathrm{~min}$ at defined $\mathrm{pH}$. The acid protease was unstable at $\mathrm{pH} 8.0$ and $\mathrm{pH} 9.0$, losing over $70 \%$ of activity after $10 \mathrm{~min}$ at $\mathrm{pH} 8.0$ and $100 \%$ after $10 \mathrm{~min}$ at $\mathrm{pH} 9.0$. The alkaline protease was unstable below pH 5.0. At pH 3.0 almost $90 \%$ of the activity was lost after 20 min incubation.

The temperature stability was analysed at $\mathrm{pH} 3.2$ and $\mathrm{pH} 7.5$ at temperatures between 30 and $60{ }^{\circ} \mathrm{C}$. The acid protease lost a small degree of activity after $60 \mathrm{~min}$ at $30^{\circ} \mathrm{C}$ but a sharp drop in activity was noted above $46{ }^{\circ} \mathrm{C}$. At $60^{\circ} \mathrm{C}$ almost $80 \%$ of activity was lost after 10 min while at 20 min no activity remained. Thus pasteurization of any preparation containing this enzyme would result in substantial inactivation. A similar pattern was obtained for the alkaline protease. It was unstable above $42{ }^{\circ} \mathrm{C} ; 90 \%$ of the activity was lost after $10 \mathrm{~min}$ at $60{ }^{\circ} \mathrm{C}$, and complete inactivation occurred after $20 \mathrm{~min}$ at $60^{\circ} \mathrm{C}$.

The acid protease was optimally active against acid denatured haemoglobin at $\mathrm{pH} 3.3$ and $42^{\circ} \mathrm{C}$. The alkaline protease showed optimal activity against azocoll at a $\mathrm{pH}$ value between 8.0 and 9.0 and at $40{ }^{\circ} \mathrm{C}$. The acid protease retained between 5 and $10 \%$ of its maximum activity at $0{ }^{\circ} \mathrm{C}$. This may in part explain its usefulness as an enzyme for chill-proofing beer, a process usually conducted at a temperature close to $0{ }^{\circ} \mathrm{C}$.

\section{Inhibition of activity}

The acid protease was inhibited by pepstatin and partially inhibited by DAN but not by EPNP or compounds known to inhibit serine, thiol or metallo proteases or the reducing agent DTT (Table 2). Therefore the enzyme is a carboxyl protease similar to pepsin, although the latter is inhibited completely by pepstatin (Umezawa, 1976), DAN (Rajagopalan et al., 1966) and EPNP (Tang, 1971). The enzyme was unaffected by divalent cations. These observations 
Table 3. Effect of $1 \mathrm{~mm}$ divalent cations on the activity of the alkaline protease secreted by C. olea 148

$\begin{array}{lc}\text { Divalent cation } & \begin{array}{c}\text { Protease activity } \\ \text { remaining }(\%)\end{array} \\ \mathrm{Control}^{*} & 100 \\ \mathrm{Ca}^{2+} & 129 \\ \mathrm{Mg}^{2+} & 103 \\ \mathrm{Mn}^{2+} & 84 \\ \mathrm{Hg}^{2+} & 2 \\ \mathrm{Cu}^{2+} & 3 \\ \mathrm{Ba}^{2+} & 58\end{array}$

* The activity of the control sample was 1.33 units measured by azocoll hydrolysis ( $\mathrm{pH} 7.5$ ).

suggest that the nature of the active site of the $C$. olea enzyme is similar to that of an enzyme from Rhodotorula glutinis (Liu et al., 1973; Kamada et al., 1972).

The alkaline protease was completely inhibited by the serine protease inhibitor PMSF and reversibly inhibited by EDTA (Table 2). It was largely unaffected by compounds known to inhibit thiol and carboxyl proteases. If after incubation of the protease with EDTA, the incubation mixture was dialysed overnight at $4{ }^{\circ} \mathrm{C}$ against assay buffer and assayed with azocoll without EDTA, little inhibition was found. Partial inhibition was found on incubation with DTT, which suggests that the protease is a serine protease with a disulphide linkage essential for activity. When assayed in the presence of $1 \mathrm{~mm}$ divalent cations (Table 3) inhibition was found with $\mathrm{Hg}^{2+}$ and $\mathrm{Cu}^{2+}$ ions, partial inhibition with $\mathrm{Mn}^{2+}$ and $\mathrm{Ba}^{2+}$, no effect with $\mathrm{Mg}^{2+}$ and some partial activation with $\mathrm{Ca}^{2+}$. As expected, excess calcium prevented inhibition of activity by EDTA. These inhibition characteristics are similar to those of $S$. lipolytica alkaline serine protease (Ogrydziak \& Scharf, 1982). Indeed, C. olea 148 may well be a strain of S. lipolytica (Kreger-van $\mathrm{Rij}, 1984$ ). In contrast, however, the $C$. olea 148 alkaline protease is sensitive to DTT, and the sensitivity to EDTA and the reactivation with $\mathrm{Ca}^{2+}$ suggest that metal ions have some role in maintaining the active conformation of the enzyme. The failure to demonstrate the ability of $\mathrm{Ca}^{2+}$ to stabilize the enzyme against changes in $\mathrm{pH}$ and temperature suggests that the role of $\mathrm{Ca}^{2+}$ is not in maintaining enzyme structure.

This work would not have been possible without the financial support of the Science and Engineering Research Council. Thanks are also due to Allied Breweries Ltd, Burton-on-Trent. T. W. Y. thanks Professor M. J. Lewis, of UC, Davis for permission to screen the yeast culture collection.

\section{REFERENCES}

Abdelal, A. T. H., Kennedy, A. H. \& Ahearn, D. G. (1977). Purification and characterisation of a neutral protease from Saccharomycopsis lipolytica. Journal of Bacteriology 130, 1125-1129.

Ahearn, D. G., Meyers, S. P. \& Nichols, R. A. (1968). Extracellular proteinases of yeast and yeastlike fungi. Applied Microbiology 16, 1370-1374.

ASHWELl, G. (1966). New colourimetric methods of sugar analysis. Methods in Enzymology 8, 93-95.

Ekland, M. W., Spinelli, J., Hiyauchi, D. \& Groninger, H. (1965). Characterisation of yeasts isolated from Pacific crab meat. Applied Microbiology 13, 985-990.

FoDA, M. S. \& EL-DiN, B. S. M. (1979). Distribution of extracellular proteolytic activities among various yeasts. Zentralblatt für Bakteriologie (Abteilung II) 134, 89-93.
HAMES, B. D. (1981). An introduction to polyacrylamide gel electrophoresis of proteins. In Gel Electrophoresis and Proteins, pp. 1-91. Edited by B. D. Hames \& D. Rickwood, Oxford \& Washington: IRL Press.

Kamada, M., Oda, K. \& Murao, S. (1972). The purification of the extracellular acid protease of Rhodotorula glutinis K24 and its general properties. Agricultural and Biological Chemistry 36, 1095-1101.

KREGER-VAN Ris, N. J. W. (1984). Genes 24. Saccharomycopsis Schiönning. In The Yeasts, a Taxonomic Study, 4th edn, p. 406. Edited by N. J. W. Kregervan Rij. Amsterdam: Elsevier.

LaSkowsKı, M. (1955). Trypsinogen and trypsin. Methods in Enzymology 2, 34-36.

LiU, C. L., Ohtsuki, K. \& Hatano, H. (1973). Inactivation of Rhodotorula glutinis acid protease by 
diazoacetyl compounds. Journal of Biochemistry $\mathbf{7 3}$, 611-673.

MacDonald, F. \& OdDs, F. C. (1980). Inducible proteinase of Candida albicans in diagnostic serology and in the pathogenesis of systemic candidosis. Journal of Medical Microbiology 13, 423-435.

MOORE, G. L. (1969). Use of Azo-dye bound collagen to measure reaction velocities of proteolytic enzymes. Analytical Biochemistry 32, 122-127.

Nelson, G. \& Young, T. W. (1986). Yeast extracellular proteolytic enzymes for chill-proofing beer. Journal of the Institute of Brewing 92, 599-603.

Ogrydziak, D. M. \& Scharf, S. J. (1982). Alkaline extracellular protease produced by Saccharomycopsis lipolytica CX 161-1B. Journal of General Microbiology 128, 1225-1234.

Ogrydziak, D. M., Demain, A. L. \& Tannenbaum, S. R. (1977). Regulation of extracellular protease production in Candida lipolytica. Biochimica et biophysica acta 497, 525-538.

Rajagopalan, T. G., Stein, W. H. \& Moore, S. (1966). The inactivation of pepsin by diazoacetylnorleucine methyl ester. Journal of Biological Chemistry 241, 4295-4297.
Remold, H., Fasmold, M. \& Staib, F. (1968). Purification and characterisation of a proteolytic enzyme from Candida albicans Biochimica et biophysica acta 167, 399-406.

RUCHEL, R. (1981). Properties of a purified proteinase from the yeast Candida albicans. Biochimica et biophysica acta 659, 99-113.

TANG, J. (1971). Specific and irreversible inactivation of pepsin by substrate-like epoxides. Journal of Biological Chemistry 246, 4510-4517.

Tobe, S., Takami, T., Ikeda, S. \& Mitsuzi, K. (1976). Production and some enzymatic properties of alkaline proteinase of Candida lipolytica. Agricultural and Biological Chemistry 40, 1087-1092.

UMEZAWA, H. (1976). Structures and activities of protease inhibitors of microbial origin. Methods in Enzymology 45, 689.

YAMADA, T. \& OGRYDZIAK, O. M. (1983). Extracellular acid proteases produced by Saccharomycopsis lipolytica. Journal of Bacteriology 154, 23-31.

Zaccharius, R. M., Zell, T. E., Morrison, J. H. \& WoDDLOCK, J. J. (1969). Glycoprotein staining following electrophoresis on acrylamide gels. Analytical Biochemistry 30, 148-152. 